\title{
Prevalence of Methicillin Resistant Staphvlococcus aureus in Children
}

\author{
Thapa S. ${ }^{1}$ Pant DK.' Ghimire P. ${ }^{1}$ Thapa PB ${ }^{2}$ \\ ${ }^{1}$ Central Department of Microbiologv. TU. Kirtipur. ${ }^{2}$ Kanti Children's Hospital. Kathmandu. Nedal
}

\section{ABSTRACT}

Background: Methicillin resistant Staphvlococcus aureus (MRSA) has been reported world wide and is becoming a clinical threat. These strains are responsible for out break of nosocomial infection. MRSA strains in the Hospital are difficult to eradicate because of the multidrug resistance. This studv was done to assess the prevalence of methicillin resistant Staphvlococcus aureus (MRSA) in pediatric patients visitin $\sigma$ Kanti children's Hospital.

Methods: The studv was conducted in the Department of Microbioloov. Kanti children's Hospital. and Kathmandu. Nepal during the period of Februarv 2004 to Iulv 2004. A total of 210 clinical samples including pus/ swabs from eve. ear. throat. vaginal. burn and wound were collected from admitted and Out - patients. All the collected samples were processed usin $\sigma$ standard protocols and analvzed for the presence of Staphvlococcus aureus. All identified Staphvlococcus aureus isolates from different clinical samples were subiected to in-Vitro antimicrobial suscentibilitv test bv Kirbv-Bauer disc diffusion method.

Results: A total of 210 clinical samples including pus/ swabs from eve. ear. throat. vaginal. burn and wound were collected from admitted and Out -patients. Among the 210 samples processed for the studv. S. aureus isolates were obtained from 65 samples which constituted $45(69.23 \%)$ were from outnatients and 20(30.77\%) were from hospitalized patients. Of 65 S. aureus isolates. $19(29.23 \%)$ were found to be MRSA which constituted $13(68.42 \%)$ from admitted patients and $6(31.57 \%$ ) from outdoor patients. Amon $\sigma$ the other antibiotics tested. $58.46 \% .30 .16 \% .26 .15 \%$ and $21.53 \%$ of $S$. aureus isolates showed resistant to ampicillin. cloxacillin. tetracvcline and ciprofloxacin respectivelv. All the MRSA isolates showed $100 \%$ resistant to ampicillin and cloxacillin. followed bv cotrimoxazole (92.1\%). tetracvcline $(40.5 \%)$ and cibrofloxacin (34.7\%). However. 100\% isolates of MRSA were sensitive to vancomvcin .

Conclusion: Vancomvcin seemed to be the onlv antimicrobial agent which showed $100 \%$ sensitivitv and mav be used as the dru $\sigma$ of choice for treating multidrug resistant MRSA infections. However. regular monitorin $\sigma$ of vancomvcin sensitivitv and routine testin $\sigma$ of other newer glvcopentides like teicoplanin should be carried out.

Kev words: multidrug resistant: prevalence: Staphvlococcus aureus 


\section{INTRODUCTION}

Methicillin resistant Staphvlococcus aureus (MRSA) strains were initiallv described in 1961 and emerged in the last decade as one of the most imbortant nosocomial bathogens. ${ }^{1}$ Infected and colonized patients provide the primarv reservoir and transmission is mainlv through hosbital staff. ${ }^{2}$ The risk factors which contribute to MRSA are excessive antibiotic usage. prolonged hosbitalization. intravascular catheterization and hosbitalisation in intensive care unit. ${ }^{3}$ With the increased incidence of MRSA, the effectiveness of penicillin and cephalosporins is questioned. In fact manv stains of MRSA exhibit resistance to both $B$ lactams and aminoglvcosides. ${ }^{4}$ Hence. knowledge of prevalence of MRSA and their antimicrobial profile becomes necessarv in the selection of appropriate empirical treatment of these infections. This work was carried out to determine the prevalence of MRSA infections and their in vitro susceptibilitv pattern to various antimicrobial agents in Kanti children's Hospital. Kathmandu. Nebal.

\section{METHODS}

The studv was conducted in the Dedartment of Microbiologv. Kanti children's Hosbital. Kathmandu. Neval to studv the prevalence of methicillin resistant Staphvlococcus aureus and antibiotic susceptibilitv pattern of isolated organism. A total of 210 clinical samples including pus/ swabs from eve. ear. throat. vaginal. burn and wound were collected from admitted and out-patients during the period of Februarv 2004 to Julv 2004. All the collected samples were inoculated on Mannitol salt agar (MSA) and incubated at $37^{\circ} \mathrm{C}$ for 24 hours. Colonies formed on MSA were picked up and Gram stained. For conformational identification of Staphvlococcus aureus. catalase test. coagulase (slide and tube) test and DNase test were also Derfomed. ${ }^{5}$ All identified Staphvlococcus aureus isolates from different clinical sambles were subiected to in-Vitro antimicrobial susceptibilitv test bv Kirbv-Bauer disc diffusion method. ${ }^{6}$
The antibiotics used in this studv were methicillin (5mcg), tetracvcline $(30 \mathrm{mcg})$. ciprofloxacin $(5 \mathrm{mcg})$. cotrimoxazole $(25 \mathrm{mcg})$. ambicillin $(10 \mathrm{mcg})$. cloxacillin $(5$ $\mathrm{mcg}$ ) and vancomvcin $(30 \mathrm{mcg})$. With a view of screening MRSA from the $S$. aureus isolates firstlv methicillin. tetracvcline. cibrofloxacin. ambicillin and cloxacillin were used. Furthermore. the MRSA isolates were further subiected to different antibiotics including vancomvcin. The accuracv of the over all testing procedure was monitored bv using Staphvlococcus aureus ATCC 25923 as reference strain.

\section{RESULTS}

\section{Isolation of Staphvlococcus aureus}

Among the 210 samples processed for the studv. S. aureus isolates were obtained from 65 samples which constituted $45(69.23 \%)$ were from outpatients and 20(30.77\%) were from hosbitalized patients (Table 1 ).

\section{Antibiotics susceptibilitv pattern of Staphvlococcus aureus isolates}

Of 65 S. aureus isolates. $19(29.23 \%)$ were found to be MRSA which constituted $13(68.42 \%)$ from admitted patients and $6(31.57 \%)$ from outdoor patients. Among the other antibiotics tested. $58.46 \% .30 .16 \% .26 .15 \%$ and $21.53 \%$ of S. aureus isolates showed resistant to ambicillin. cloxacillin. tetracvcline and ciprofloxacin respectivelv (Table 2 ).

All the MRSA isolates showed $100 \%$ resistant to ambicillin and cloxacillin. followed bv cotrimoxazole $(92.1 \%)$. tetracvcline $(40.5 \%)$ and ciprofloxacin $(34.7 \%)$. However. $100 \%$ isolates of MRSA were sensitive to vancomvcin (Table 3).

\section{DISCUSSION}

Our findings showed that 19 (29.23\%) isolates of S.aureus were methicillin resistant. Other antibiotics were used Table 1. Isolates of S. aureus in Admitted and out patients of different age groups

\begin{tabular}{|lllllll|}
\hline Age (vear) & \multicolumn{3}{c}{ Out Patients } & \multicolumn{3}{c|}{ Admitted Patients } \\
& $\begin{array}{l}\text { No. of sambles } \\
\text { taken }\end{array}$ & $\begin{array}{l}\text { No. of S.aureus } \\
\text { isolates }\end{array}$ & $\begin{array}{l}\text { Percentage of } \\
\text { S.aureus isolates }\end{array}$ & $\begin{array}{l}\text { No. of sambles } \\
\text { taken }\end{array}$ & $\begin{array}{l}\text { No. of S. } \\
\text { urues solates }\end{array}$ & $\begin{array}{l}\text { Percentage of } \\
\text { S.aureus isolates }\end{array}$ \\
\hline $0-3$ & 75 & 30 & $40 \%$ & 43 & 13 & $30.23 \%$ \\
$4-6$ & 18 & 5 & $27.7 \%$ & 15 & 3 & $20 \%$ \\
$7-9$ & 14 & 6 & $42.85 \%$ & 3 & 0 & $0 \%$ \\
$10-12$ & 22 & 2 & $9.09 \%$ & 10 & 3 & $30 \%$ \\
$13-15$ & 8 & 2 & $25 \%$ & 2 & 1 & $50 \%$ \\
Total & 137 & 45 & & 73 & 20 & \\
\hline
\end{tabular}


Prevalence of Methicillin Resistant Staphvlococcus...

\begin{tabular}{|c|c|c|c|c|c|}
\hline \multirow{2}{*}{ Antibiotics } & \multirow{2}{*}{$\begin{array}{l}\text { Total } \\
\text { S.aureus } \\
\text { isolates }\end{array}$} & \multicolumn{2}{|c|}{ Sensitive } & \multicolumn{2}{|c|}{ Resistance } \\
\hline & & No. & $\%$ & No. & $\%$ \\
\hline Methicillin & 65 & 46 & 70.77 & 19 & 29.23 \\
\hline Tetracvcline & 65 & 48 & 73.84 & 17 & 26.15 \\
\hline Cibrofloxacin & 65 & 51 & 78.46 & 14 & 21.53 \\
\hline Ambicillin & 65 & 27 & 41.53 & 38 & 58.46 \\
\hline Cloxacillin & 65 & 45 & 69.23 & 20 & 30.16 \\
\hline
\end{tabular}

so as to interpret the resistant pattern of S.aureus in regard with MRSA in which higher percentage of $S$. aureus isolates were found to be resistant to ampicillin (58.46\%) followed bv gentamicin (36.92\%). cloxacillin $(30.16 \%)$. tetracvcline $(26.15 \%)$ and ciprofloxacin $(21.53 \%)$.

It has been observed that ciprofloxacin was the most effective drug $\mathbf{1 7 8 . 4 6 \% )}$ for S.aureus followed

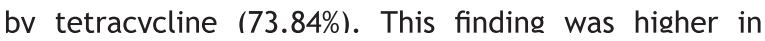
combarision to the finding of Pokharel et al $113 \%)$. Fraise et al $(17 \%)$ in Nursing homes in maior UK citv. Tanaka et al $(22 \%)$ at Tottori Universitv Hospital. Japan and Raibhandari et al (54.9\%) in Kathmandu. Nepal. ${ }^{7-10}$ There might be several risk factors for acauisition of MRSA. Patients having a historv of previous hospitalization. increased length of hospitalization. acutelv ill in an ICU. chronic disease state. prior and prolonged antibiotics therapv. exposure to colonized or infected patient. presence of wound and use of invasive indwelling devices (including endotracheal tubes) are some of the important risk factors associated with the accuisition of MRSA. However, this finding was agreement with another studv conducted bv Lamichhane et al $(31.43 \%)$ in Kathmandu. Nebal. ${ }^{11}$

The drug resistance of MRSA was highest with ampicillin $(100 \%)$ and cloxacillin $(100 \%)$ followed bv cotrimoxazole (92.1\%). tetracvcline $(40.5 \%)$ and ciprofloxacin (34.7\%). However. all MRSA strains were sensitive to vancomvcin.

A similar tvpe of studv in India showed that vancomvcin and Ciprofloxacin were the most effective drug for Staphvlococcus aureus. ${ }^{12}$ The studv in Shiraz-Iran also found that vancomvcin $(100 \%)$ was the most effective drug followed bv chlorambhenicol (94\%) and ciprofloxacin $(87 \%)$ for treating MRSA infections. ${ }^{13}$

MRSA from different clinical sambles at Kanti Children's Hospital showed $100 \%$ resistance to penicillin. ampicillin. cloxacillin. and cephalexin. However. all the MRSA isolates were sensitive to vancornvcin $(100 \%)$ Lamichhane et al. ${ }^{11}$
Table 3. Antibiotic susceptibilitv Datterns as shown bv the MRSA Isolates

\begin{tabular}{|lll|}
\hline Antibiotics & Resistant & \multicolumn{1}{c|}{ Sensitive } \\
\hline Vancomvcin ( $30 \mathrm{mcg}$ ) & - & $100 \%$ \\
Ciprofloxacin (5 mcg) & $34.7 \%$ & $65.3 \%$ \\
Tetracvcline (30 mcg) & $40.5 \%$ & $59.5 \%$ \\
Cotrimoxazole (25 mcg) & $92.1 \%$ & $7.9 \%$ \\
Ampicillin (10 mcg) & $100 \%$ & $0 \%$ \\
Cloxacillin (5 mcg) & $100 \%$ & $0 \%$ \\
\hline \hline
\end{tabular}

Raibhandari et al also studied antibiotic sensitivitv Dattern of MRSA and found that $100 \%$ strains of MRSA at Bir Hospital were sensitive to vancomvcin. ${ }^{10}$

Hence, vancomvcin is the drug of choice for MRSA infection. Vancomvcin seems to be the onlv antimicrobial agent which showed $100 \%$ sensitivitv and mav be used as the drug of choice for treating multidrug resistant MRSA infections. However. regular monitoring of vancomvcin sensitivitv and routine testing should be carried out. Further. the regular surveillance of hosbital associated infections including monitoring antibiotic sensitivitv Dattern of MRSA and formulation of definite antibiotic Dolicv mav be heloful for reducing the incidence of MRSA infection.

\section{ACKNOWLEDGEMENT}

The authors are thankful to the department of Microbiologv. Kanti children's hosbital. Maharaigung to conduct this studv.

\section{REFERENCES}

1. Maple P. Hamilton- Miller I. Brumfitt W. World wide antibiotic resistance in methicillin resistant Staphvlococcus aureus. Lancet. 1989: 1:537-540

2. McDonald $M$. The epidemiolog ${ }_{\mathrm{V}}$ of methicillin resistant Staphvlococcus aureus: Surøical relevance 20 vears on. Aust N Z I Suro. 1997: 67:682-685.

3. Doebbeling BN. The exidemiolo $\sigma_{\mathbf{V}}$ of methicillin resistant Staphvlococcus aureus colonization and infection. I Chemotherapeutics. 1995: 7 (Suppl.3):99-103.

4. Thornsberrv C. The development of antimicrobial resistance in Staphvlococci. I Antimicrob Chemotherap. 1998: 21 (Suppl.C):916.

5. Baird-Parker AC. Methods for identifvino Staphvlococci and Micrococci. The societv for applied microbiolog $\sigma_{\mathrm{V}}$ technical Series. No. 14. Academic press. London 1979.

6. NCCLS. Performance standards for antimicrobial disc susceptibilitv tests. 6th Ed. Approved Standard NCCLS Document M2- A6 (ISBNI - 56238 - 308- 6). NCCLS. 940 West Vallev Road. Suit 1400. Wavne. Pennsvlvania. 1997:19087-1898. 
7. Pokharel. BM (1993) Bacteriological studv at TU Teaching Hospital. Kathmandu. Nepal. Iournal of Institute of Medicine. 1993: 15: 217-221.

8. Fraise AP. Mithell K.. O'Brien SI.. Oldfield K. Wise R. Methicillin resistant Staphvlococcus aureus (MRSA) in nursing homes in a Maior UK citv: an anonvmized point prevalence survev. Evidemiolo $\sigma_{\mathrm{V}}$ and Infections. 1997: 118:1-5.

9. Tanaka Y. Adachi A. Ogoshi T. Ohnishi Y. Kobavashi N. Fukatus Y. Antibiotic susceptibilitv of Staphvlococcus sDs collected from the entrance hall of the new dispensarv at Tottori Universitv Hospital. Yona $\sigma_{0}$ Acta Medica._Iapan Iulv 1996: 109

10. Raibhandari R. Manandhar SP. Shrestha I. Prevalence and antibiotics susceptibilitv pattern of methicillin resistant Staphvlococcus aureus (MRSA) in Bir Hospital. M.Sc.dissertation. Central Department of Microbioloov. Tribhuvan Universitv Kirtipur. Ktm. Nebal. 2002.
11. Lamichhane R. Adhikari RP. Sherchand IB. (1999) Studv of methicillin resistance Staphvlococcus aureus (MRSA) isolated from different clinical samples. M.Sc. dissertation. Central Department of Microbiolo $\sigma_{\mathbf{v}}$. Tribhuvan Universitv Kirtibur. Ktm. Nebal. 1999.

12. Deodhar L. Vvas B. Antibiotic resistance pattern of methicillin resistance Staphvlococcus aureus. Department of Microbioloov. Bombav Hospital. Medical Research Center. Mumbai. India. 1994.

13. Alborzi A. Pourabbas BA. Salchi H. Pourabbas BH. Oboodi B. Paniehshani MR. Prevalence and pattern of antibiotic Sensibilitv of methicillin Sensitive and methicillin resistant Staphvlococcus. A research article published bv Clinical Microbiologv Research Center. and Department of Pharmacologv. Shiraz Universitv of Medical Sciences. Shiraz. Iran. 2000. 